\title{
Multi-faceted Professional Development Designs for Science Teachers' Self-efficacy for Inquiry-based Teaching: A Critical Review
}

\author{
Kumudu Seneviratne ${ }^{1, *}$, Junainah Abd Hamid ${ }^{2}$, Ali Khatibi ${ }^{2}$, Ferdous Azam², Sepali Sudasinghe ${ }^{3}$ \\ ${ }^{1}$ Faculty of Education, University of Colombo, Sri Lanka \\ ${ }^{2}$ School of Management, Management and Science University, Malaysia \\ ${ }^{3}$ Management and Science University Colombo Learning Centre, Sri Lanka
}

Copyright $\mathrm{C} 2019$ by authors, all rights reserved. Authors agree that this article remains permanently open access under the terms of the Creative Commons Attribution License 4.0 International License

\begin{abstract}
This review's overarching goal is to synthesize what the research tells us about the impact of teacher professional development programs for both pre-service and in-service science teachers' self-efficacy for the enactment of inquiry-based instruction (IBI) in the classroom. This in-depth critical review attempts to illuminate insights and direction of multi-faceted Professional Development Designs (PDDs) in relation to two eminent research fields in science education; self-efficacy and inquiry-based teaching(IBT). It involves a computerized, web-based search of relevant studies mainly consisting of academic and peer-reviewed journals and well-known book chapters. 43 empirical studies that met specific search criteria were selected for the review based on indications of the reputation of the research and recent impacts factors. Additionally, the methodological aspect is considered to draw a more complete and holistic view of the related studies regarding self-efficacy and inquiry-based science teaching. The prominent implications of the review were the mediator or moderator effect of self-efficacy in the relationship of professional development interventions and the enactment of inquiry-based science teaching, particularly, for pre-service teachers and the broader understanding of the nature of PDDs either form of science content courses or science methods courses. Out of which, deep understanding of scientific inquiry, strong practical experience with designing, developing, implementing and assessing IBT, and skills for guiding and organizing students to conduct inquiry activities were found to be key features of PDDs. Other functional and methodological implications are also pointed out for further research related to the effects of different innovative professional learning communities promoting the self-efficacy beliefs for inquiry-based teaching in science.
\end{abstract}

Keywords Professional Development Designs,
Self-efficacy, Inquiry-based Science, Pre-service, In-service

\section{Introduction}

In many countries around the world, curriculum reform has included teaching and learning experiences that place the learner in the role of a producer of knowledge in addition to the continuing role of one who acquires knowledge and skills. This approach takes several forms with different names, but "inquiry-based instruction" is widely recognized in education. Teaching with inquiry is a relatively complex and challenging activity. The word "dilemma" to describe different challenges to teaching scientific inquiry as suggested by Anderson [4] implies the internal difficulty rather than external difficulty. Internal difficulties for science teachers for teaching scientific inquiry mainly include the beliefs, values related to students, teaching and the purpose of education. The feeling of confidence about one's ability to add this teaching method to one's repertory of teaching skills is an important predictor of its happening in the classroom. This confidence is known as self-efficacy. Teacher's sense of efficacy for inquiry teaching is an important part of enacting inquiry in classrooms and schools.

\subsection{Overview of the General Concept of Self-efficacy}

In general, whether with respect to teaching, teaching with inquiry, or any other task, teacher's sense of efficacy is defined as one's belief of his or her capabilities to bring about desired outcomes of students' engagement, achievement, and learning, even among those students who may be difficult or unmotivated (Bandura, 1997). Bandura 
[7] further elaborated self-efficacy as a person's judgments about his or her ability "to organize and execute courses of action required dealing with prospective situations that contain many ambiguous, unpredictable, and often stressful elements"(p.200). This construct is analogous to self-confidence which is an individual's belief in his or her ability to perform tasks competently. The construct has established itself as having significant implications in education settings as it deals with three domains of the instructional behavior, namely, student engagement, instructional strategies, and classroom management. Tschannen-Moran and Woolfolk Hoy [76] highlighted the significant implications of teacher self-efficacy in creating a dynamic, student-centered learning environment in which students take ownership of their leaning.

In his theory of social learning, Bandura [7] outlined two components: (1) personal efficacy and (2) outcome expectancy. Personal efficacy refers to the conviction that an individual can successfully execute the behavior required to produce the desired outcome. An outcome expectancy is defined as an individual's estimate that a given behavior will lead to certain outcomes. As per Bandura [7], the development of an individual's personal efficacy beliefs could be fostered through four major sources of influence: mastery experiences, vicarious experiences, social persuasions, and physiological and emotional states. Mastery experiences provide the most authentic evidence of one's success, while vicarious experiences (for an example, observing an experienced teacher succeed at activities) strengthen self -efficacy providing a useful model enabling pre-service teachers to both acquire pedagogical skills and gain confidence in being able to try out such activities in practice. The third efficacy source is social persuasion which stems from significant others effective in helping an individual to reappraise his or her competencies. Supporting someone's capacity to succeed on a given task through self-improvement leads to more sustainable outcome expectations. The fourth way to influence efficacy beliefs is through the interpretation of physical and emotional reactions. Individuals' perceptions of effective arousal can be viewed either as energy or as an incumbency depending on their sense of efficacy.

\subsection{Overview of the General Concept Scientific Inquiry}

The notion of "Scientific inquiry" has been the focus in science education for more than three decades (National Research Council (NRC), [41, 55, 77]. An authentic inquiry refers to advancing and distinguishing between inquiries as means and ends [1]. "Inquiry as means" (or inquiry in science) refers to an inquiry as an instructional approach intended to help students develop understandings of science content (i.e., content serves as an end or instructional outcome). "Inquiry as ends" (or inquiry about science) refers to an inquiry as an instructional outcome:
Students learn to do inquiry in the context of science content and develop epistemological understandings about Nature of Science (NOS) and the development of scientific knowledge, as well as relevant inquiry skills [4]. The publication Inquiry and the National Science Education Standards [41] identified the following five essential features of classroom inquiry:(1)Learner engages in scientifically oriented questions; (2)Learner gives priority to evidence in responding to questions;(3) Learners formulate explanations from evidence to address scientifically oriented questions;(4) Learners evaluate their explanations in light of alternative explanations, particularly those reflecting scientific understanding; and (5)Learners communicate and justify their proposed explanations(p.24).

Researchers and educators have advocated the positive influence of inquiry-based learning (IBL) on student's science learning both at an effective and cognitive domain level $[39,49]$ Authentic inquiry skills includes identifying problems, generating research questions, designing and conducting investigations, formulating, communicating, and defending hypotheses, models, and explanations[4].

Irrespective of how inquiry has been conceptualized during the past 50 years or so, research has consistently indicated that what is enacted in classrooms is mostly incommensurate with visions of inquiry put forth in reform documents, (e.g.,[4,32,41] Absence of inquiry-based instruction from science teachers' ordinary teaching practice repertoire might be mainly attributed to two key factors (1) lack of teacher preparation programs to design and enact science instruction through inquiry-based learning $[3.4,9,39]$ and (2) lack of use of self-efficacy as an organizing construct or framework(a process variable) to be considered in in-service training[12].

\section{Objectives}

The aim of this paper is to review studies on teacher professional development for science teachers' self-efficacy for inquiry-based instruction. This is addressed by following three research questions:

1. Do the professional development programs have an impact on teachers' adoption of inquiry-based instruction into their practice in the science classroom?

2. Is teachers' sense of efficacy related to the enactment of scientific inquiry in the classroom?

3. Do the professional development programs have an impact on the teacher's sense of efficacy, which in turn affects their readiness to adopt inquiry-based instruction?

\section{Methods}

The scope of this review does not use of either content 
analysis or meta-analysis such that it simply provides a review to elucidate the interconnectedness among professional development programs, teacher's sense of efficacy and enactment of inquiry-based instruction.

The search process was from the research studies either separately on professional development programs for scientific inquiry teaching, teacher's sense of efficacy for inquiry-based instruction or enactment of inquiry-based instruction in the science classroom or on their combination to maximize the potential studies. The studies cited in two major education databases; ERIC and PsycINFO were used to search potentially appropriate studies published after 2004. The search was conducted with the words: 'professional development', 'teacher training', 'teacher self-efficacy', 'inquiry-based instruction', 'authentic inquiry', and combination of these words using the connector "and". Types of primary and secondary references were limited to 'peer-reviewed journals, principally based on their higher impact factors. These were Science Education (Impact factor: 3.035), International Journal of Science Education (2017 Impact Factor1.325 as in 2017), Journal of Research in Science Teaching (Impact factor 3.21 as in 2019), and Learning and Instruction (Impact Factor: 3.967). The articles form these journals were then scanned to meet the following inclusion criteria:

(1) Purpose of the study: The research questions, purpose, aim or hypothesis addressed science teachers' self-efficacy and enactment of scientific inquiry

(2) Context(s) of the study: Studies in school settings with either pre-service or in-service science teachers or both whose objective were developing effective instructional strategies in scientific inquiry

(3) Research Methods: The studies of empirically based with quantitative, qualitative or mixed designs.

(4) Variety of Data: Studies included at least two data sources either to describe the changes in teacher's self-efficacy or to triangulate qualitative and quantitative data

A study which met with all four criteria was included in the review 46 eligible articles were identified. Then the titles of the references were scanned and the abstracts of those seemed relevant were read. Table 1 provides an overview of these 46 articles, including context, data sources and the type of inquiry focused on the investigation. 
Table 1. Context, data sources and the focus of selected studies $(n=46)$

\begin{tabular}{|c|c|c|c|c|}
\hline Author(s) & Participants & $\begin{array}{l}\text { Level of the } \\
\text { school }\end{array}$ & Data sources & The focus of the study(Inquiry or self-efficacy or both) \\
\hline E. Ahokoski, et al., (2017) & $\begin{array}{l}\text { In-service teachers } \\
(\mathrm{n}=102) \text { from six } \\
\text { schools in five } \\
\text { Finnish cities who } \\
\text { attended the Ark of } \\
\text { Inquiry training } \\
\text { course. }\end{array}$ & Secondary & $\begin{array}{l}\text { Pre and post-Self-efficacy and perceptions of } \\
\text { inquiry learning instruments }\end{array}$ & Effect of inquiry learning the training on teacher self-efficacy \\
\hline $\begin{array}{l}\text { S. Almuntasheri, R.M. Gillies, } \\
\text { T. Wright.(2016) }\end{array}$ & $\begin{array}{l}\text { In-service } \\
(\mathrm{n}=6) \text { from Saudi } \\
\text { Arabia }\end{array}$ & Secondary & Pre and post achievement tests & $\begin{array}{l}\text { Comparison of PD with 5E's guided -inquiry model to teacher-directed } \\
\text { approach }\end{array}$ \\
\hline F. Bardone, et al (2017) & $\begin{array}{l}\text { In-service } \\
(\mathrm{n}=7) \\
\text { teachers in the } \\
\text { Estonian general } \\
\text { education system } \\
\text { who taught } \\
2-12\end{array}$ & Secondary & Ethnographic study & RRI as a meaningful engagement in and for an Inquiry \\
\hline S. E. Bell, S.S. Sexton. (2018) & $\begin{array}{l}\text { In-service }(650 \\
\text { from New } \\
\text { and } 610 \text { from } \\
\text { Arkansas) }\end{array}$ & Elementary & $\begin{array}{l}\text { SCIQ in New Zealand and PMSI in Arkansas } \\
\text { and Face-to-face discussions }\end{array}$ & Effect of PD based on interconnections of content, policy, and practice \\
\hline A. Berg, F.M. Mensah (2014) & $\begin{array}{lr}\text { Certified } & \text { K-6 } \\
\text { in-service teachers } \\
\text { with no science } \\
\text { degrees at at } \\
\text { Morningview } \\
\text { Elementary in } \\
\text { August 2010-June } \\
2011 \text { in USA }\end{array}$ & Elementary & $\begin{array}{l}\text { a comparative case study with observations, } \\
\text { semi-structured interviews }\end{array}$ & $\begin{array}{l}\text { Multiple tensions felt by instructors: focusing on science pedagogy and } \\
\text { other school subjects; the necessity of science instruction and their lack o } \\
\text { content knowledge; and finally, the innate tension deciding if curriculum } \\
\text { should be used as a script, a supplement, a starting point, or not to be usec }\end{array}$ \\
\hline B. R. Brand, S.J. Moore.2011) & $\begin{array}{l}\text { In-service } \\
(\mathrm{n}=30)\end{array}$ & Elementary & Pre-post experimental design & $\begin{array}{l}\text { constructivist sociocultural professional development model on inquiry - } \\
\text { based strategies }\end{array}$ \\
\hline M. Carlick.(2013) & $\begin{array}{l}\text { Pre-service } \\
(\mathrm{n}=117)\end{array}$ & Secondary & $\begin{array}{l}\text { A quasi-experimental design, the } \\
\text { technology-embedded scientific inquiry } \\
\text { self-efficacy adapted from Ebenezer (2008) }\end{array}$ & $\begin{array}{l}\text { Technology-Embedded Scientific Inquiry model \& Teachers } \\
\text { Self-Efficacy }\end{array}$ \\
\hline $\begin{array}{l}\text { T.J. Cartwright, J. Atwood. } \\
\text { (2014) }\end{array}$ & Pre-service & Elementary & $\begin{array}{l}\text { Traditional pre-tests, retrospective pre-tests, } \\
\text { and post-tests with STEBI-B }\end{array}$ & $\begin{array}{l}\text { The occurrence of response-shift bias scales relating to outcome } \\
\text { expectancy, value, and relevancy of science }\end{array}$ \\
\hline J.L Chen. (2018) & $\begin{array}{l}\text { Pre-service } \\
(\mathrm{n}=3)\end{array}$ & Secondary & collective case study & Not about any specific inquiry type or model \\
\hline Chen et al., (2016) & $\begin{array}{l}\text { Pre-service } \\
(\mathrm{n}=3)\end{array}$ & Elementary & video-taped observations & $\begin{array}{l}\text { Impact of teacher preparation on argument-based inquiry instruction and } \\
\text { four instructive roles of teachers: coach, participant, dispenser, and } \\
\text { moderator to tackle different situations when attempting to engende } \\
\text { student ownership of ideas and activities. }\end{array}$ \\
\hline
\end{tabular}




\begin{tabular}{|c|c|c|c|c|}
\hline $\begin{array}{l}\text { W. DiBiase, } \\
\text { McDonald.(2015) }\end{array}$ & $\begin{array}{l}\text { In-service } \\
(\mathrm{n}=275)\end{array}$ & Secondary & Survey(not specifically mentioned) & $\begin{array}{l}\text { Beliefs about inquiry and class size, accountability, curricular demands, } \\
\text { and administrative support are perceived as constraints, impeding the use } \\
\text { of inquiry }\end{array}$ \\
\hline I. Decoito, P. Myszkal.(2018) & In-service & Secondary & Survey (not specifically mentioned) & $\begin{array}{l}\text { Influence of a longitudinal STEM outreach program on science } \\
\text { instruction and teachers' self-efficacy and beliefs and disconnect between } \\
\text { beliefs and implementation }\end{array}$ \\
\hline X. Fazio, W. Melville. (2008) & $\begin{array}{l}\text { In-service } \\
(\mathrm{n}=4)\end{array}$ & Secondary & $\begin{array}{l}\text { A qualitative case study(collaborative action } \\
\text { research project) }\end{array}$ & $\begin{array}{l}\text { Value of collaborative action research on personal understanding of both } \\
\text { scientific inquiry and the nature of science }\end{array}$ \\
\hline A. Filippi, D. Agarwal.(2017) & $\begin{array}{l}\text { Italian In-service } \\
(\mathrm{n}=14) \\
\text { Educators } \\
(\mathrm{n}=30) \text { from India, } \\
\text { Germany, Canada, } \\
\text { and Denmark } \\
\text { under the Ark of } \\
\text { Inquiry Project }\end{array}$ & $\begin{array}{l}\text { Secondary } \\
\text { (STEM) }\end{array}$ & $\begin{array}{l}\text { Online Google forms Survey(Ark of Inquiry } \\
\text { First Impressions) and in-person interview } \\
\text { during focus groups and project meetings }\end{array}$ & $\begin{array}{l}\text { Five phases of Inquiry-based learning design using online resources in } \\
\text { developing the idea 'teacher as designer' and factors hindering the growth } \\
\text { of teachers as designers and facilitators of student-centered ISBE } \\
\text { curriculum }\end{array}$ \\
\hline E.M. Furtak et al., (2012) & In-service & Elementary & $\begin{array}{l}\text { Meta-study- } 37 \text { experimental and } \\
\text { quasi-experimental studies on inquiry that } \\
\text { took place between and including } 1996 \text { to } \\
2006\end{array}$ & $\begin{array}{l}\text { Framework for inquiry-based teaching that distinguished between } \\
\text { cognitive features of the activity and degree of guidance given to students }\end{array}$ \\
\hline S.B. Gutierez. (2015) & $\begin{array}{l}\text { In-service } \\
(\mathrm{n}=30) \text { in } \\
\text { Philippines }\end{array}$ & Elementary & $\begin{array}{l}\text { Qualitative with interviews and post-lesson } \\
\text { reflections and discussions }\end{array}$ & $\begin{array}{l}\text { Three barriers to were identified1) the lack of support, training, and } \\
\text { available inquiry-based materials; 2) the overemphasis on assessing } \\
\text { content learning rather than learning through inquiry; and 3) the } \\
\text { misconception, difficulty, and time-consuming nature of inquiry-based } \\
\text { teaching. }\end{array}$ \\
\hline J. Ireland.(2014) & In-service $(n=20)$ & Elementary & Phenomenographic interviews & $\begin{array}{l}\text { Approaches to teaching for inquiry from Experience-centered category to } \\
\text { Question-centered category }\end{array}$ \\
\hline $\begin{array}{l}\text { C.M. Knaggs, T.A. Sondergeld. } \\
\text { (2015) }\end{array}$ & $\begin{array}{l}\text { Pre-service } \\
(\mathrm{n}=26)\end{array}$ & Elementary & $\begin{array}{l}\text { Mixed methods. This study uses measure with } \\
\text { Intervention mixed methods of concurrent } \\
\text { design. Our study is considered repeated } \\
\text { measures because we are measuring student } \\
\text { SE over time. }\end{array}$ & $\begin{array}{l}\text { Effect of a semester-long science content course, } \\
\text { Using Bandura's concept of SE as a Conceptual framework. Significant } \\
\text { increases in science SE on both subscales (personal efficacy and outcome } \\
\text { expectancy). Qualitative data showed that students communicated an } \\
\text { increased sense of confidence with regard to the discipline of science. } \\
\text { Combining our } \\
\text { Findings resulted in several meta-inferences, one of which showed } \\
\text { students growing as both confident learners of science and teachers of } \\
\text { science simultaneously. }\end{array}$ \\
\hline M. Kim, A. Tan. (2011) & Pre - service $(\mathrm{n}=38)$ & Elementary & $\begin{array}{l}\text { Reflective writings and group discussions on } \\
\text { their lived experiences and concerns }\end{array}$ & $\begin{array}{l}\text { Sought conflicts and negotiations that they experience as they make } \\
\text { decisions regarding practical work throughout their course }\end{array}$ \\
\hline $\begin{array}{l}\text { J.M. Lakin, } \\
\text { Wallace.(2015) }\end{array}$ & In-service & Secondary & $\begin{array}{l}\text { Teachers' and students' Self-reports on use of } \\
\text { inquiry strategy }\end{array}$ & $\begin{array}{l}\text { Effect of knowledge of inquiry practices, and related pedagogical content } \\
\text { knowledge in professional development experiences on inquiry strategy } \\
\text { use and preferences for inquiry }\end{array}$ \\
\hline C. K. Lee, M. Shea .(2016) & $\begin{array}{l}\text { Pre-service } \\
\mathrm{N}=54(14,20,20) \\
\text { enrolled in science } \\
\text { method class at a }\end{array}$ & Elementary & $\begin{array}{l}\text { Pre-test and Posttest Questionnaires \& } \\
\text { semi-structured One-on-one interviews }\end{array}$ & $\begin{array}{l}\text { Teachers' understanding of inquiry-based science teaching and impact of } \\
\text { science method course on acquiring skills and self-efficacy in teaching } \\
\text { inquiry-based science }\end{array}$ \\
\hline
\end{tabular}




\begin{tabular}{|c|c|c|c|c|}
\hline & $\begin{array}{l}\text { Liberal Arts College } \\
\text { in United States }\end{array}$ & & & \\
\hline O. Lee et al., (2004) & $\begin{array}{l}\text { In-service } \\
(\mathrm{n}=53) \text { third and } \\
\text { fourth grade teachers } \\
\text { at six schools in USA }\end{array}$ & Elementary & $\begin{array}{l}\text { A mixed method with focus group interviews, } \\
\text { questionnaire and classroom observations }\end{array}$ & $\begin{array}{l}\text { Initial beliefs and practices about inquiry-based science and the effect of } \\
\text { PD intervention through instructional units and workshops on Initia } \\
\text { beliefs and practices about inquiry-based science }\end{array}$ \\
\hline $\begin{array}{l}\text { L.L. Liang, G.M. Richardson. } \\
\text { (2009) }\end{array}$ & $\begin{array}{l}\text { Pre-service } \\
(\mathrm{n}=54) \text { enrolled in } \\
\text { four sections of an } \\
\text { interdisciplinary } \\
\text { science course at a } \\
\text { small private } \\
\text { university in the } \\
\text { Mid-Atlantic area }\end{array}$ & Elementary & $\begin{array}{l}\text { A quasi-experimental Design( STEB1-B) } \\
\text { with qualitative }\end{array}$ & $\begin{array}{l}\text { The positive effect of Scaffolded Student Directed Inquiry on persona } \\
\text { Science Teaching Efficacy }\end{array}$ \\
\hline C. Lotter, et al., (2016) & In-service $(\mathrm{n}=25)$ & $\begin{array}{l}\text { Secondary } \\
\text { (Middle) }\end{array}$ & $\begin{array}{llr}\text { inquiry } & \text { teaching } & \text { efficacy } \\
\text { instrument( personal self-efficacy } & \text { and } \\
\text { outcome expectancy) } & \\
\text { pre/post classroom observations using } \\
\text { inquiry observation protocol }\end{array}$ & $\begin{array}{l}\text { The positive effect of } \mathrm{PD} \text { with practice-teaching and reflection sessions on } \\
\text { their personal self-efficacy and outcome expectancy across } 5 \text { essentia } \\
\text { features of classroom inquiry }\end{array}$ \\
\hline C. Lotter, et al., (2018) & In-service & $\begin{array}{l}\text { Secondary } \\
\text { (Middle) }\end{array}$ & $\begin{array}{l}\text { Electronic Quality of Inquiry Protocol } \\
\text { (EQUIP) before and after the program } \\
\text { (Marshall, Smart \& Horton, 2010) teachers' } \\
\text { inquiry teaching efficacy using Teaching } \\
\text { Science as Inquiry (TSI; Dira-Smolleck, } \\
\text { 2004) instrument }\end{array}$ & $\begin{array}{l}\text { Changes in middle school teachers' beliefs about inquiry, implementation } \\
\text { of inquiry practices, and self-efficacy to teach science through inquiry }\end{array}$ \\
\hline J.L. Maeng, et al., (2017) & $\begin{array}{l}\text { In-service } \\
(\mathrm{n}=235)\end{array}$ & Elementary & $\begin{array}{l}\text { a randomized controlled trial design using } \\
\text { videotaped classroom observations across } \\
\text { four-time points and teacher-generated } \\
\text { descriptions of lessons }\end{array}$ & $\begin{array}{l}\text { Positive Effect of a statewide professional development (PD included a } \\
\text { summer institute that situated explicit NOS instruction within the contex } \\
\text { of problem-based learning (PBL)) on elementary teachers' classroom } \\
\text { implementation Nature of science instruction. }\end{array}$ \\
\hline P. Magee, R. Flessner. (2012) & $\begin{array}{l}\text { Pre-service } \\
(\mathrm{n}=49)\end{array}$ & Elementary & variety of artifacts(reflective teacher journal) & $\begin{array}{l}3 \text { different types of inquiry experiences; PST has driven science inquiry } \\
\text { and a mathematics inquiry where PSTs were learners and a science } \\
\text { inquiry where PSTs were teachers. }\end{array}$ \\
\hline W. Melville, et al.,(2008) & $\begin{array}{l}\text { Pre-service } \\
(\mathrm{n}=12)\end{array}$ & Secondary & $\begin{array}{l}\text { personal narratives of pre-service science } \\
\text { teachers }\end{array}$ & $\begin{array}{l}\text { inquiry-learning experiences in a science instruction course on (they al } \\
\text { had an undergraduate science degree) their capacity to reflect on the } \\
\text { challenges involved in implementing inquiry into classrooms }\end{array}$ \\
\hline J.N. Mikeska, et al.,(2017) & In-service $(n=99)$ & $\begin{array}{l}\text { Secondary } \\
\text { (Biology) }\end{array}$ & Survey on teachers' value-added measures & Student-directed investigation-related experiences \\
\hline J.J.Mintzes.(2013) & In-service & Elementary & $\begin{array}{l}\text { non-equivalent control group experimental } \\
\text { design and Structured clinical interviews }\end{array}$ & Changes in personal self-efficacy and outcome expectancy \\
\hline P.D.Morrell, J.B. Carroll.(2003) & $\begin{array}{l}\text { Pre-service } \\
(\mathrm{n}=75)\end{array}$ & Elementary & pre and post survey with STEBI-B & $\begin{array}{l}\text { impact of science methods courses, student teaching and science conten } \\
\text { courses on elementary pre-service } \\
\text { Teachers' science teaching self-efficacy. methods } \\
\text { course positively impacted the elementary pre-service } \\
\text { Teachers' PSTE. The scores on this scale significantly increased over the } \\
\text { duration of each methods course. }\end{array}$ \\
\hline
\end{tabular}


Examined how science-specific and generic instructional practices relate

to student achievement in secondary science classrooms results showed J. Nam, E.Seung, M. Go.(2013) Pre-service(n=3 $\quad \begin{array}{ll}\text { Secondary } \\ \text { (middle) }\end{array} \quad \begin{aligned} & \text { Reformed Teaching Observation Protocol, } \\ & \text { Teacher's reflections }\end{aligned}$ Science teachers who had well-managed classroom environments and who provided opportunities for their students to engage in student-directed investigation-related experiences were more likely to have increased student outcomes, as determined by teachers' value-added measures

Pre-service

teachers

( $\mathrm{n}$-104) enrolled in a

one-semester science

D. Palmer, J. Dixon, , one-sent

J.Archer.(2015) regional university

Elementary Survey and Interviews(STEB1-B))

South-eastern

Australia
Effect of a traditional science content course tailored to the needs to the particular teachers coupled with teacher enthusiasm which utilize a wide range of teaching techniques that enhance learning on increase of selfsustained even after a1 0 -months delay period during the course as well

\begin{tabular}{lll}
\hline \multicolumn{3}{c}{$\begin{array}{l}\text { Pre-service } \\
(\mathrm{n}=44) \text { teachers }\end{array}$} \\
$\begin{array}{l}\text { Mattended in an } \\
\text { undergraduate Papaevripidou, M. Elementary } \\
\text { Irakleous,Z.C. Zacharia.(2017) } \\
\text { elementary teaching } \\
\text { methods course in } \\
\text { Cyprus }\end{array}$ & $\begin{array}{l}\text { Documentary analysis of curriculum } \\
\text { materials with the constant comparative } \\
\text { method }\end{array}$ \\
\hline
\end{tabular}

\begin{tabular}{llll}
$\begin{array}{l}\text { T.J.Posnanski. } \\
(2007)\end{array}$ & Pre-service & Elementary & Impact study \\
\hline A. Qablan.(2016) & In-service $(\mathrm{n}=8)$ & Secondary & $\begin{array}{l}\text { A qualitative design utilizing inductive } \\
\text { analysis }\end{array}$ \\
\hline
\end{tabular}

A redesigned Geoscience Content course inquiry-based instructional method in a content-based course on self-efficacy. Findings indicate that the modeling of effective instruction, exposure to science standards, overviews of the nature of science, and practical experiences with school-based curricular activities serve to improve the educational experiences and self-efficacy beliefs of the pre-service teachers.

Effect of a subject-specific professional development program of Inquiry-oriented lessons with Twenty-first-century science practices. Impact of teacher professional development on science instruction elementary teachers' changes in science content knowledge; self-efficacy

in teaching science; instructional practices in science; and contextual

J.H. Sandholtz, C. Ringstaff.

(2013)
In-service
Elementary
Teacher survey, self-efficacy assessment content knowledge tests, interviews and classroom observations factors. Teachers experienced a significant increase in their knowledge of earth science in the second year. Their overall self-efficacy scores also increased significantly in the second year. Changes in instructional practices in science were largely sustained during the second year but were influenced by contextual factors such as resources, curricular demands, administrators' support and support from other teachers.

\begin{tabular}{|c|c|c|c|c|}
\hline L.Sandra.(2017) & In-service & Elementary & $\begin{array}{l}\text { An experimental, pretest-posttest control } \\
\text { group }\end{array}$ & Positive effect of professional interventions on large-scale inquiry project \\
\hline $\begin{array}{l}\text { A.S. Gencer, J. Çakıroglu } \\
(2003)\end{array}$ & $\begin{array}{l}\text { Turkish Pre-service } \\
(\mathrm{n}=646)\end{array}$ & $\begin{array}{l}\text { Elementary/S } \\
\text { econdary }\end{array}$ & STEBI-B) and classroom control inventory. & $\begin{array}{l}\text { Secondary, pre-service teachers were more efficacious than the } \\
\text { elementary counterparts on the two dimensions of the STEBI-B. } \\
\text { However, all participants were found to be more interventionist on the }\end{array}$ \\
\hline
\end{tabular}




\begin{tabular}{|c|c|c|c|c|}
\hline & & & & $\begin{array}{l}\text { instructional management and non-interventionist on the people } \\
\text { management. No significant gender and education level differences on the } \\
\text { subscales of the ABCC Inventory. }\end{array}$ \\
\hline G. Silm, et al.,(2017) & $\begin{array}{l}\text { In-service } \\
(\mathrm{n}=497) \text { from } 10 \\
\text { countries under Ark } \\
\text { of Inquiry project } \\
\text { lined to the RRI } \\
\text { approach }\end{array}$ & $\begin{array}{l}\text { Secondary } \\
\text { (STEM) }\end{array}$ & Pre and post questionnaire with TSES & $\begin{array}{l}\text { Self-efficacy and attitudes towards inquiry approach and Effect of training } \\
\text { on teacher efficacy }\end{array}$ \\
\hline Smit, R. et al (2017) & Pre-service $(\mathrm{n}=121)$ & $\begin{array}{l}\text { Secondary } \\
\text { (Biology) }\end{array}$ & $\begin{array}{l}\text { Pre-post-research design. (cognitive beliefs, } \\
\text { affective states, and self-efficacy) }\end{array}$ & $\begin{array}{l}\text { Effect of Short PCK related training seminars on teaching scientific } \\
\text { inquiry on teacher's attitudes towards scientific inquiry }\end{array}$ \\
\hline $\begin{array}{lr}\text { L.E. } & \text { Swackhamer, } \\
\text { K.Koellner,C. } & \text { Basile, } \\
\text { D.Kimbrough. (2009) } & \end{array}$ & $\begin{array}{l}\text { in-service } \\
\text { teachers }(\mathrm{N}=88)\end{array}$ & Secondary & $\begin{array}{l}\text { Pre and post survey instruments with } \\
\text { STEBI-B }\end{array}$ & Not about any specific inquiry type or model \\
\hline $\begin{array}{l}\text { B.G. Swan, K.J. Wolf, J. } \\
\text { Cano.(2011) }\end{array}$ & $\begin{array}{l}\text { Of } 17 \text { Pre-service, } 3 \\
\text { student teachers who } \\
\text { participated } \\
\text { continuously from } \\
\text { first year to third year } \\
\text { at the Ohio State } \\
\text { University in } 2004\end{array}$ & Secondary & Teacher's Sense of Efficacy Scale(TSES) & Changes if self-efficacy from student teaching to third years of teaching \\
\hline $\begin{array}{l}\text { C.Tekkaya,J. Çakıroglu, O. } \\
\text { Özkan.(2004) }\end{array}$ & $\begin{array}{lr}\text { Turkish } & \text { Pre-service, } \\
\text { senior } & \text { science } \\
\text { education } & \text { major } \\
\text { students } & \\
(\mathrm{n}=299) & \\
\end{array}$ & Secondary & $\begin{array}{l}\text { STEBI-B } \\
\text { and the Science Concepts Test }\end{array}$ & $\begin{array}{l}\text { Confident about teaching science but some misconceptions about basic } \\
\text { science concepts }\end{array}$ \\
\hline W.A.Zimmerman, et al., (2017) & In-service & Elementary & Pre-and Post-experimental design & $\begin{array}{l}\text { Impact of professional development on the relationship between teaching } \\
\text { behaviors and teacher efficacy. Results indicate a significant interaction } \\
\text { effect; for teachers who received the training, the relationship between } \\
\text { behaviors and teacher efficacy was negative, while for teachers in the } \\
\text { control group this relationship was positive }\end{array}$ \\
\hline
\end{tabular}




\section{Results}

As per in table 1, overall, $26(60 \%)$ studies included in-service teachers, out of which $11(25 \%)$ studies at the elementary level and $15(35 \%)$ studies at the secondary level. Out of $17(40 \%)$ studies involved with pre-service science teachers, $8(19 \%)$ were at Elementary level while the rest; $9(21 \%)$ studies were at the secondary level. As indicated in the Table 1 (column 4), inquiry teaching is typically measured by questionnaires[2, 41], Google surveys[27] as well as reputed rating scales such as Science Curriculum Implementation Questionnaire (SCIQ), and Practical Measures Survey Item (PMSI)[9], Scientific Process Skills Test[29], Electronic Quality of Inquiry Protocol (EQUIP)[44], Reformed Teaching Observation Protocol[53]. Science Teaching Efficacy Belief has been typically measured by two main rating scales; (1) Science Teaching Efficacy Belief Instrument (STEBI-B) for in-service and (STEBI-A for pre-service teachers) [17, 42, 44, 60, 72], and (2) Teacher's Sense of Efficacy Scale (TSES)) developed by Tschannen-Moran and Woolfolk Hoy [76] [69, 73].

\subsection{Do the Professional Development (PD) Programs Have an Impact on Teachers' Adoption of Inquiry-based Instruction into Their Practice in the Science Classroom?}

This section focuses on how professional development experiences can influence pre-service and in-service science teachers for the enactment of scientific inquiry in the classroom. PD focusing on science teachers has a significant impact on teacher development to include how they implement and use innovative curricula. Research highlights that PD should help teachers be more effective in supporting students' learning by facilitating teachers improving not only their knowledge and practice but also their conceptions and beliefs. The assertion by previous researchers, 'effective PD being sustained and intensive rather short-term programs "would be important in this regard.

Overall, 16 studies revealed information about different approaches of professional development in inquiry-based science, 6 studies with pre-service science teachers while the rest were with the in-service.

\subsubsection{Pre-service Experiences}

Much work has been done to better understand how to support pre-service teachers (PSTs) at all levels to become more competent and comfortable with Inquiry-based teaching (IBT). Some studies focused on PD support upon identifying the PSTs' understanding of inquiry-based science teaching $[41,46]$. Most of the pre-service teachers have simplistic views of inquiry-based teaching [39]). Lee and Shea further pointed out ", they believe that doing hands-on-activities is inquiry teaching, and equate doing laboratory work with inquiry learning. In fact, not all hands-on-activity is an inquiry, and not all inquiry is hands-on (P.220). Similarly, National Science Education Standards points out hands-on- activities are essential but that students must have minds-on experiences as well. As examined by Magee and Flessner[46] pre-service elementary teachers hold the belief that inquiry is "laissez-faire"- that teachers can teach anything or in whatever way they prefer, and that inquiry is chaos(p.358). Lee and Shea [41] clearly highlighted the two prerequisites for developing good inquiry-based science teaching (1) a better understanding of the precise nature of inquiry by teachers and (2) a sufficient learning atmosphere which encourages students to raise questions and be able to propose feasible ways to solve problems.

In studies investigating experiences that support inquiry science teaching by pre-service elementary-school teachers, use of inquiry was evident with PD on argument-based inquiry instruction identifying four instructive roles of teachers: coach, participant, dispenser, and moderator to tackle different situations when attempting to engender student ownership of ideas and activities[18]; Inquiry Based Practical Work [34]; Pedagogical design Capacity (PDC) for Inquiry-based learning [56]; and Science method course focused on the concepts of inquiry-based teaching [41]. The study of Magee and Flessner [46] showed how three different types of inquiry experiences; PST drove science inquiry and a mathematics inquiry where PSTs were learners and a science inquiry where PSTs were teachers have been successful for pre-service teachers. Calik in 2013 has investigated the impact of PD with the Technology-Embedded Scientific Inquiry model for pre-service secondary teachers in using inquiry. In addition, the literature reported the relationship between pre-service teachers' inquiry experience in a science instruction course and their capacity to reflect on the challenges involved in implementing inquiry into classrooms [47]. The authors found pre-service teachers with extensive inquiry experiences perceived implementation challenges principally in terms of teaching and student learning and they pointed out how this contrasted with the perceptions of pre-service teachers with limited inquiry experience for whom the main concerns relate to the negative perceptions of others, time, the curriculum, and materials.

\subsubsection{In-service Experiences}

Effective implementation of inquiry-based science teaching requires both pre-service as well in-service science teachers to understand what inquiry is, the benefits and challenges of using this strategy, and to have extended experiences with an inquiry through properly planned PD experiences. The studies on PD in this regard for in-service -elementary science teachers disclosed multifaceted PD designs including, Integrated PD based on interconnections of content, policy and practice[9]; PD framework for 
inquiry-based teaching that distinguished between cognitive features of the activity and degree of guidance given to students[28] and professional interventions on large-scale inquiry project[68].

When a constructivist sociocultural professional-development model was adopted in a two-year school-wide initiative, the researchers noticed a change in elementary school teachers' pedagogical skills in teaching science as inquiry, specifically the way they introduced ideas during instruction $[11,42,58]$. They also noticed changes in their instruction; for example, they began introducing ideas with questions and providing more opportunities for students' discussions. In addition, the study of Ireland [37] supported the literature with six approaches to teaching for inquiry identified by in-service elementary teachers, clustered within three categories. These approaches were categorized as Free and Illustrated Inquiries as part of an Experience-centered category, Solution and Method Inquiries as part of a Problem-centered category, and Topic and Chaperoned Inquiries as part of a Question-centered category. This study contributes to our theoretical understanding of how teachers approach Inquiry Teaching and suggest fertile areas of future research into this valued and influential phenomenon broadly known as 'Inquiry Teaching' [37].

The study of Bell and Sexton in 2018 investigated how the teachers were experiencing PD explicitly based on the interconnections of content, policy, and practice. They reported as a result of participation in the first phase of the PD, teachers in both Arkanas and in Newzealand have been aware of how they build on what their students' knowledge and have experienced. More importantly, this study notes the teachers need both time and opportunity to experience learning but also support as they then implement their new learning into their own classroom practice (p.117). Within the literature, it also noted the use of some other forms of PD. Qablan [63] investigated the impact of a subject-specific professional development program designed for in-service secondary science teachers' ability to design inquiry-oriented lessons that integrate twenty-first-century science practices and implement them in the classroom. The author suggested the need of modifying the program's training materials to focus more on two dimensions of inquiry(asking scientifically oriented questions and designing and carrying out investigations)where the in-service participants demonstrated less ability. A PD with collaborative action research had an impact on personal understanding of both scientific inquiry and the nature of science [26]. Filippi. and Agarwal [27] presented the model of ISBE implementation in science teacher training with the idea of "teacher as a designer" through five phases of inquiry-based science education, i.e. motivation stage, orientation stage, stabilization stage, completing stage and integration stage as introduced by Trna and colleagues in 2012. They discussed how the Ark of Inquiry has tried to walk the teachers through its online resources presenting the factors hindering the growth of teachers as designers and facilitators of student-centered ISBE curriculum (p.262-263). It is also evident about relationships between self-reported inquiry strategy use, preferences for inquiry, knowledge of inquiry practices, and related pedagogical content knowledge (PCK) after a PD program [38]. They found that teachers tended to self-report higher levels of inquiry strategy use than their students perceived. Further, there were no significant correlations between either knowledge of inquiry practices or PCK and self-reported inquiry strategy use.

Maeng and colleagues[45] examined the impact of a statewide professional development (PD) which included a summer institute that situated explicit nature of science ( NOS) instruction within the context of problem-based learning (PBL)) on elementary teachers' classroom implementation of NOS instruction. Results demonstrated that situated PD that contextualizes explicit NOS instruction within PBL facilitated teachers' explicit NOS instruction compared to teachers who did not receive such instruction. In addition, Sandholtz and Ring staff [67] reported the impact of teacher professional development on science instruction, science elementary teachers' changes in science content knowledge, self-efficacy in teaching science, instructional practices in science, and contextual factors. Results found that teachers experienced a significant increase in their knowledge of earth science as well as their overall self-efficacy scores in the second year. Furthermore, changes in instructional practices in science were largely sustained during the second year but were influenced by contextual factors such as resources, curricular demands, administrators' support and support from other teachers.

Accordingly, the following assertions in the form of critics are posed emanating from the 16 studies.

Assertion I: Inquiry is not "laissez-faire', but blended with hands-on and minds-on experiences

Research has shown that the teacher is the crucial player in implementing inquiry-based learning (IBL) $[33,56,80]$. Science teachers in general, more importantly, the pre-service teachers need to have a deep understanding of scientific inquiry, strong practical experience with designing, developing, implementing and assessing IBL, and skills for guiding and organizing students to conduct inquiry activities $[25,30,77]$. In addition, Crawford [20] emphasized the need for teachers' pedagogical content knowledge (PCK) for effective implementation of IBL.

Therefore, it strongly suggests a framework that guarantees effective professional development programs for teachers on learning about inquiry as a blended form of hands-on and minds-on experiences, rather an inquiry as chaos. In this attempt, teachers' role needs to be well instilled, as a "facilitator", rather than the sole" owner" of information[61], which also requires them to be transformed from instructors to designers of IBL 
experiences.

Assertion II: Essential features of classroom inquiry vs. inquiry continuum

For a fundamental understanding of science and scientific inquiry and its enactment in the classroom, it requires science teachers' deep cognitive engagement in the inquiry process. The cognitive engagement in the inquiry process should be well grounded not only with essential features of classroom inquiry but also the inquiry continuum which classifies classroom inquiry into different levels from traditional confirmatory laboratory experiences to open inquiry [42]. In traditional confirmatory laboratory experiences, students just follow the given step-by-step procedures to verify known principles, whereas, in structured inquiry, the teacher presents a question, lab equipment, and procedures for students to complete the inquiry. Subsequently, students need to make conclusions based on their findings or results. At the second level of the inquiry continuum, known as guided inquiry, the teacher provides a question and lab equipment, while the students design the procedure, analyze data, and make conclusions. In the student-directed inquiry, the third level, the teacher presents a topic and lets students develop their own questions and design their own investigations. The highest level of the inquiry continuum is referred to as open inquiry or student research inquiry ((p.52).

\subsection{Is Pre-service and in-service Teachers' Sense of Efficacy Related to Enactment of Scientific Inquiry in the Classroom?}

Self-efficacy beliefs that relate to teachers' motivation and performance have been an important area of concern for both pre-service and in-service teacher education in relation to any teaching task. The teachers in general and beginning teachers among them are more likely to plan for and conduct inquiry-based teaching when they feel confident (i.e. self-efficacious) about being able to appropriately use inquiry methods to achieve valued goals. In the literature for teachers, it noted how varying degrees of self-efficacy determine if teachers will be more willing to plan and implement innovative instructional strategies as follows:

(1) Teachers with higher teacher efficacy "are more open to new ideas and are more willing to experiment with new methods to meet the needs of their students" [76, P.783]

(2) Teachers' higher sense of efficacy is related to their readiness to adopt new teaching methods such as inquiry[78]

(3) Teacher efficacy is an important prerequisite for teacher's readiness to start using new methods. Teacher's higher sense of efficacy is related to perceiving fewer barriers for implementing inquiry-based learning (IBL) [68, P.318]
(4) An individual with a high sense of teacher self-efficacy is more inclined to create a dynamic, student-centered learning environment in which students take ownership of their learning; whereas teachers with a low sense of self-efficacy would likely to devote more time to non-academic, managerial tasks [7]

(5) Teacher candidates at two different institutions might have similarly high teaching self-efficacy; however, they differ in their perception of environmental factors such as supportive principal behaviors, cooperating teacher competence, and number of class preparations that contributed to teacher self-efficacy

More importantly, in the context of pre-service science, it is evident that high self-efficacy beliefs were more in favor of creating inquiry-based classroom environments. For example, an increased sense of self-efficacy for teaching using inquiry has been attributed to continuous success in understanding the science content taught, learning different pedagogical techniques and practices, and being able to teach the learned science content to primary school children during the practicum [54]. In addition, several other studies have described the correlation between beginning teachers' avoidance of the use of inquiry approach and their low general self-confidence for teaching (at both the elementary and secondary levels) $[5,81]$. These studies further elaborated the nature of teaching strategies engaged by the beginning teachers which are low-risk instructional activities such as staying closer to the textbook and using reading- and writing-based teaching strategies rather than hands-on activities [6, 24, 52].

Accordingly, the following two assertions in the form of critics are posed emanating from the studies.

Assertion 1: Higher the self-efficacious more likely to plan for and conduct inquiry-based teaching

The evidence across studies on self-efficacy has consistently shown that an individual's perceived self-efficacy contributes significantly to the level of his or her motivation and performance accomplishments. The literature also revealed three different efficacy beliefs ; (1) self-efficacy beliefs of judgments of the student, (2) teacher's beliefs in their own instructional efficacy, and (3) teacher's beliefs about the collective efficacy of their school [71]. Out of them, teacher's beliefs in their own instructional efficacy are of uttermost important in transforming them as designers of inquiry-based learning in the classroom. As innovative teachers, these would, in turn, integrate new pedagogical skills essential for inquiry with increased professional interest and attitudes towards IBL. However, the different forms of self-efficacy could have an impact on each other as it is a context-specific construct.

Assertion II: Self-efficacy as a personal cognitive construct operates as a continuous reciprocal interaction between behavioral and environmental determinants. 
Devi and colleagues [23] elaborated what meant by Bandura's social cognitive theory "behavioral competencies, social competencies, and cognitive skills are acquired through observational learning" (p.722). The individual observes the modeled event and forms a cognitive construct, which shapes future behaviors. A person will choose to engage in specific behaviors that he or she has acquired by observational learning. Scaria and colleagues [66] pointed out Bandura's concept of triadic reciprocal determinism. Triadic reciprocal determinism was explained as "a continuous reciprocal interaction between personal, behavioral, and environmental determinants". Environment (E): Environment refers to the factors that can affect a person's behaviors. There are social and physical environments. Personal (P): Seeking the cause of human behaviors in dispositional sources in the form of instincts, drives, traits, wisdom, thoughts, feelings, beliefs, self-perception, goals, intentions and other motivational forces within the individual. Behavioral (B): Knowledge and skill to perform a given behavior. These three factors such as environment, personal and behaviors constantly influence each other. Behaviors are not simply the result of the environment and the person, just as the environment is not simply the result of the person and behaviors [15]. Under environmental factors, the contextual factors such as resources, curricular demands, administrators' support and support from other teachers seem to be crucial determinants of teacher's beliefs about the collective efficacy of their school. This collective efficacy of their school in turn Influence on sustained changes in instructional practices in science over the years [67]. Thus, interaction among these three factors needs to be facilitated in order to have a sustained change in the overall self-efficacy of an individual.

\subsection{Do the Professional Development Programs Have an Impact on Teacher's Sense of Efficacy, Which in Turn Affect for Their Readiness to Adopt Inquiry-based Instruction?}

Previous research suggests high-quality PD programs have the potential to shape teachers' self-efficacy beliefs in general as well as in inquiry-based science teaching.

\subsubsection{Pre-service}

As empirically evident from the 50 studies in this review, 20 studies devoted to enhancing science teaching efficacy, out of which 10 studies focused on efficacy beliefs of pre-service teachers through multifaceted PD designs. The majority of these studies had focused on pre-service elementary teachers, might be due to the fact that many pre-service elementary teachers had unsuccessful science learning experiences in school and therefore developed negative attitudes and low levels of confidence in learning and teaching science $[14,43,75]$. Consequently, in recent years many studies have been devoted to enhancing the science teaching self-efficacy of pre-service elementary teachers through either science content courses[17-61] or science method courses $[16,41,70,82]$. However, the impact of science content courses (i.e. those aimed at teaching the concepts of science) in enhancing pre-service elementary teachers' science teaching efficacy has been more mixed. Palmer and colleagues [59] pointed out how other researchers revealed both positive and negative correlation between science content courses and personal teaching science efficacy. In other studies such as Windschitl [82] found the inadequacy of only authentic views of inquiry and reflection more deeply about their projects in the method course for subsequent practice of inquiry in teaching. In recent studies the impact has been improved through changing the design of the science content course, taking a more inquiry-oriented approach [42].

In analyzing the different interventions of science methods course employed to enhance the science teaching efficacy, the literature suggests that field placements which include opportunities for authentic science research experiences are relatively effective[41,82]. Integration of self-efficacy sources as proposed by Bandura [7] within professional development activities is also evident(1)mastery experiences[35]; (2) vicarious experiences[62, 64], (3) verbal persuasion, and (4) physiological states (Gunning \& Menash,2011). Authors such as Slim and colleagues [68] reported the success of PD programs associated with both content knowledge and pedagogical content knowledge in self-efficacy attitudes with respect to teaching scientific inquiry. Furthermore, authors such as Calick [16] reported a positive interaction between technology-embedded scientific inquiry (TESI) professional model and senior science student teachers' (SSSTs) self-efficacy.

\subsubsection{In-service}

The results of PD on efficacy enhancement of in-service teachers' in science teaching have been more mixed. Previous research revealed a positive impact of professional development attempts which emerged from Bandura's Social Cognitive Theory. For example, the study of Mintzes and colleagues [50] reported an impact of sustained Professional Learning Communities (PLCs) that featured on Demonstration Laboratories, Lesson Study, and annual Summer Institutes on self-efficacy in science teaching. Similarly, the study of Sandholtz and Ringstaff [67] found a significant increase in knowledge of earth science and sustained instructional practices in science in line with increased overall efficacy. Furthermore, Lotter and colleagues'[44] study investigated a professional development model (focused on both inquiry pedagogy and science content) designed to improve teachers' inquiry teaching efficacy as well as the quality of their inquiry instruction through engaging teachers in practice-teaching and reflection sessions. This study provides implications of 
this PD model for moving teachers towards the implementation of new instructional techniques as well as the influence of a supportive school community on teachers' efficacy with inquiry instruction. Slim and Colleagues [68] also revealed a positive impact of a specially designed PD program (which allow trainees to perform under three roles ;( as learners, (2) as thinkers, and (3) as reflective practitioners.) on the student engagement scale of self-efficacy and attitudes towards inquiry-based learning. At the same time, some authors reported the effect of PD on enhanced knowledge of science content and stronger beliefs about the importance of science instruction with diverse student groups, yet no change in their actual practice [40]. The study of Ahokoski and colleagues [2] is important to broaden our understanding of the self-efficacy profiles among the participants in PD activities; Low, moderate and high throughout the PD program. This study found that the three groups' self-efficacy profiles differed in terms of teachers' perceptions of resources of inquiry learning and their anxiety toward inquiry learning, yet, were satisfied in general with the PD program(p.305).

On the other extreme, Zimmerman [83] examined the impact of professional development on the relationship between teaching behaviors and teacher efficacy. Results indicated a significant interaction effect; for teachers who received the training, the relationship between behaviors and teacher efficacy was negative, while for teachers in the control group this relationship was positive. Similarly, the study of Decoito and Myszkal [21] investigated the influence of a longitudinal STEM outreach program on science instruction and teachers' self-efficacy and beliefs. Findings suggested that although Grade 6, 7, and 8 teachers possessed the confidence and heightened beliefs in their abilities to teach science and mathematics, interactive hands-on learning only occurred about half the time in their classrooms. Although participants agreed with the goals of STEM education, as well as expressed confidence in their ability to execute them, there was a disconnection between beliefs and implementation in practice.

Accordingly, there are two prominent assertions from the general findings of these studies.

Assertion I: Mixed results of the studies may be elusive and further studies are needed.

The two latter studies located in this section, [21, 82], contrary to eighteen former studies, approached the fact that the impact of professional development on the relationship between teaching behaviors and teacher efficacy is not always positive. In other words, the PD designs might lead to heighten the efficacy beliefs, yet, yield less influence on their actual practice in inquiry instruction in the classroom. Furthermore, mixed results with regard to multi-faceted PD programs towards teachers' science teaching efficacy also direct our insights about two effective means of PD: (1) taking a science content course more inquiry-oriented approach [42], and (2) a science methods course more with field placements [41, 82]. In addition, the findings propose to revisit the impact of PD on the fact if it is tailored to the needs of the teachers at the classroom. Therefore, studies on the impact of PD on teachers' efficacy beliefs and attitudes towards inquiry-based teaching are inconclusive and further probe of the issue in different contexts is highly recommended.

Assertion II: Higher the use of self-efficacy sources, more the positive impact on science teaching efficacy enhancement

The studies revealed a more positive impact of PD emerged from four specific sources of efficacy beliefs: mastery experiences, vicarious experiences, verbal persuasion, and arousal as identified by Bandura [7]. The central principle of Bandura's theory is the social context of learning. Devi and colleagues [23] pointed out the concept of triadic reciprocal determinism which explained as "a continuous reciprocal interaction between personal, behavioral, and environmental determinants. Individuals gain knowledge from interaction with their environment. In addition, Bandura asserts the environment is inclusive of observing and modeling other individuals' attitudes and behaviors (p.721). The study findings[50,44,67] reported how sustained Professional Learning Communities (PLCs) that featured on Demonstration Laboratories, Lesson Study, annual Summer Institutes, and practice-teaching and reflection sessions have affected on self-efficacy in science teaching. Therefore, tailoring the common forms of professional development; workshops, seminars and formal college or university courses to use of self-efficacy sources with the "can do" belief is highly recommended for science teaching efficacy enhancement.

\subsection{Concerns and/or Limitations about Using Inquiry in the Classroom}

Despite the best efforts in both the professional education and professional development of science teachers, the inquiry is not being implemented in the classroom [22]. Success in teaching with inquiry is highly correlated with teachers' interpretations of the limitations /challenges associated with this pedagogy. The review of studies identified the following main issues in relation to self-efficacy for enacting inquiry-based teaching in the classroom.

1) Issues such as class size, accountability, curricular demands, and administrative support are perceived as constraints that impede the use of inquiry. Many classroom teachers feel the pressure of time constraints; either the length of the class (block versus non-block schedule) or the amount of state-demanded curriculum leaves insufficient time to implement inquiry practices in the classroom

2) Subject matter taught is less conducive to inquiry-based instruction and, therefore, effects how teachers practice inquiry in the class 
3) Covering a required amount of curriculum for a mandatory assessment often requires a teacher to make choices on the implementation of inquiry-based instruction in the classroom or use other instructional methods[55]

4) The time-related issue as per teachers' beliefs (Inquiry takes too much time from classroom learning $(75 \%)$ and that it takes too much time to develop the lessons) and students will not use their time effectively or efficiently (66\%) during inquiry activities [22]

5) Assessment- difficulty to cover the state goals of assessment while using inquiry methodology [22]

6) Teacher knowledge-feeling about the need for teachers' extensive background knowledge and ability to teach using inquiry [22]

7) Student and external limitations [22]

8) Lack of support, training and available inquiry-based materials; the overemphasis on assessing content learning rather than learning through inquiry; and the misconception, difficulty, and time-consuming nature of inquiry-based teaching [84]

9) Influence of contextual factors such as resources, curricular demands, administrators' support and support from other teachers on sustained changes in instructional practices in science over the years [67]

\section{Discussion}

This critical review aimed at attesting the linkage between multi-faceted Professional Development Designs (PDD) and Science teachers' self-efficacy for inquiry-based teaching. Several prominent suggestions are presented for the more effective implementation of inquiry-based science in the classroom through PDD tailored to self-efficacy enhancement.

First, studies exploring the linkage between Professional Development Designs and science teachers' self-efficacy for inquiry-based teaching have been pervasively based on either pre-service or in-service teachers. In addition, the pre-service science teachers may be engaged in PDD featured in cooperative learning groups of pre-service and in-service teachers together. Such a professional learning community may allow the pre-service to experience more vicarious and verbal persuasion experiences from practicing teachers which leads to heighten their self efficacy.

Second, obviously more rigorous 'experimentally designed studies' are required on models of inquiry-based science education (ISBE) implementation in blended learning environments for science teacher training. Such models as explained by Flippi and Agarwal [27] need to consist of five stages: (1) Motivation stage for increasing professional interest and attitudes towards ISBE, (2) Orientation stage for acquiring knowledge for ISBE, (3) Stabilization stage for solving of simple tasks of ISBE application, (4) Completing stage for solving of complicated tasks of ISBE application, and (5) Integration stage for solving of teaching problem situation in school practice. It is essential to redesign the professional development course structure integrating online and face-to-face activities.

Third, studies conducted in socio-scientific contexts generate mixed results with respect to the impact of professional development programs on transforming science teachers as designers of ISBE learning experiences. The self-efficacy related contextual factors play a crucial role to decide if the impact is sustained or not. Obviously, more research is needed to enlighten the scope of the studies in continuous reciprocal interaction between personal, behavioral, and environmental determinants with the aid of gathering more qualitative data in addition to quantitative data. Therefore, employing mixed-methods designs is recommended.

Finally and more importantly, the inclusion of self-efficacy (as a valuable process variable to be considered during training, and a desirable outcome of training) into studies investigating the linkage between the teacher preparation and the enactment of ISBE in the classroom might be more elucidative. The exploitation of self-efficacy as mediating and moderating constituents in manifesting the linkage between the professional development activity and teacher's actual practice of ISBE was well understood in this critical review.

In conclusion, it is impossible to disclaim interactions between the multi-faceted professional development designs and science teachers' self-efficacy for inquiry-based teaching. However, it needs to be acknowledged that this interaction has to be supported with more researches of mixed method designs.

\section{REFERENCES}

[1] F. Abd-El-Khalick, S.Boujaoude, R. Duschl, N.G. Lederman, A. Mamalok-Naaman, R., Hofstein, M. Niaz, D. Treagust, H.L. Tuan. Inquiry in science education: International perspectives, Science Education, 88, 397-419, 2004.

[2] E. Ahokoski, M. Korventausta, K. Veermans, T. Jaakkla. Teachers' experiences of an inquiry learning training course in Finland, International Journal of Science Education, Vol.28, No. 4, 305-314, 2017.

[3] S. Almuntasheri, R.M. Gillies, T. Wright. The effectiveness of a guided inquiry-based, teachers' professional development program on Saudi students' understanding of Density, Science Education Journal, Vol. 27, No.1, 16-39, 2016.

[4] R. D. Anderson. Reforming science teaching: What research says about inquiry? Journal of Science Teacher Education, Vol.13, No.1, 1-12, 2002.

[5] K. Appleton. Developing teachers' Science pedagogical 
content knowledge through mentoring elementary, Journal of Science Teacher Education, Vol. 19, No. 6, 523-545, 2008.

[6] K. Appleton, I. Kindt. Beginning elementary teachers' development as teachers of science, Journal of Science Education, Vol.13, 43-61, 2002. doi:10.1023/A:10151818 09961

[7] A. Bandura. Self-efficacy: The foundation of agency. In W. J. Perrig \& A. Grob (Eds.), Control of human behavior, mental processes, and consciousness (pp. 17-33), Mahwah, NJ: Erlbaum, 2000.

[8] E. Bardon, M. Burget, K. Saage, M. Taaler. Making sense of responsible research and innovation in science education through inquiry-based learning: Examples from the field, International Journal of Science Education, Vol. 28, No.4, 293-304, 2017.

[9] S.E., Bell, S. E. Sexton, Science education professional development for primary/elementary teachers: A Tale of two systems, International Journal of Science Education, Vol. 29, No.2.117-123, 2018.

[10] A. Berg, F. M. Mensah. De-marginalizing science in the elementary classroom by coaching teachers to address perceived dilemmas, Education policy analysis archives, Vol.22, 57, 2014

[11] B. R. Brand, S. Moore. Enhancing teachers' application of inquiry - based strategies using a constructivist sociocultural professional development model, International Journal of Science Education, Vol.33, 889913, 2011. doi:10.1080/09500691003739374

[12] N. Bray-Clark, R. Bates. Self-Efficacy Beliefs and Teacher Effectiveness: Implications for Professional Development, The Professional Educator, Vol. 26, No. 1 13-22, 2003. Retrieved April 23, 2015, from http://files.eric.ed.gov/fullt ext/EJ842387.pdf

[13] M. Bursal. Changes in American pre-service elementary teachers' efficacy beliefs and anxieties during a science methods course, Science Education International, Vol. 23, No.1, 40-55, 2012.

[14] R. R. Buss. Efficacy for teaching primary science and mathematics compared to other content, School Science and Mathematics, Vol. 110, No. 6, 290-297, 2010. http://dx.doi:10.1111/j.1949-8594.2010.00037.x

[15] K. Bussey, A. Bandura. Social cognitive theory of gender development and differentiation, Psychology Review, Vol.106, 676-713, 1999.

[16] Calik, M. Effect of technology-embedded, inquiry on senior science student teachers' self-efficacy, EURASIA Journal of Science, Mathematics and Technology Education, Vol. 9. No.3, 223-232, 2013.

[17] T. J. Cartwright, J. Atwood. Elementary pre-service teachers 'Response-Shift Bias: Self- efficacy, and attitudes toward science. International Journal of Science Education, Vol.36, No.14, 889-913, 2014.

[18] Y. C. Chen, B. Hand, L. Norton-Meier. Teacher roles of questioning in early elementary science classrooms: A framework promoting student cognitive complexities in argumentation, Research in Science Education, 1-33, 2016. http://dx.doi:10.1007/s11165-015-9506-6
[19] J. A. Cobert, R.S. Brown, S. Choi, S. Thomas. An investigation of the impacts of teacher-driven professional development on pedagogy and student learning, Teacher Education Quarterly, 135-154, 2008.

[20] B. A. Crawford. Embracing the essence of inquiry: New roles of the science teacher, Journal of Research in Science Teaching, Vol.37, No. 9,916-937, 2000.

[21] I. Decoito, P. Myszkal. Connecting science instruction and teachers' self-efficacy and beliefs in STEM education. Journal of Science Teacher Education, 2018.

[22] W. DiBiase, J. R. McDonald. Science teacher attitudes toward inquiry-based teaching and learning. The Clearing House: A Journal of Educational Strategies, Issues, and Ideas, Vol.88 No.2, 29-38, 2015.

[23] B. Devi, B. Khandelwal, M. Das. Application of Bandura's social cognitive theory in the technology-enhanced, blended learning environment, International Journal of Applied Research, Vol.3, No.1, 721-724, 2017.

[24] C. J. Eick, C. J. Reed. What makes an inquiry-oriented science teacher? The influence of learning histories on student-teacher role identity and practice, Science Education, Vol.86, 401-416, 2002. doi:10.1002/sce.10020

[25] R. F. Elmore. Bridging the gap between standards and achievement: The imperative for professional development in education. Washington, DC: Albert Shanker Institute, 2002.

[26] X. Fazio, W. Melville. Science teacher development through collaborative action research, Teacher Development, Vol. 12, No. 3, 193-209, 2008.

[27] A.Filippi, D. Agarwal. Teachers from instructors to Designers of inquiry-based Science, Technology, Engineering, and Mathematics Education: How effective inquiry-based science education implementation can result in innovative teachers and students, Science Education Journal, Vol.28, No. 4, 258-268, 2017.

[28] E. M. Furtak, T. Seidel, H.Iverson, D.C. Briggs. Experimental and quasi-experimental studies of inquiry-based science teaching a meta-analysis, Review of Educational Research, Vol.82, No.3, 300-329, 2012.

[29] S. U. Gezer. A case study on pre-service science teachers' laboratory usage self-efficacy and scientific process skill, Procedia- Social and Behavioral Sciences, Vol. 174, 1158-1165, 2015.

[30] B. Jeanpierre, K. Oberhauser, C. Freeman. Characteristics of professional development of that effect change in secondary science teachers' classroom practices, Journal of Research in Science Teaching, Vol.42, No.6, 668-690, 2005.

[31] E.J.S., Kang, A. Julie, J.A. Bianchini, G.J. Kelly. Crossing the border from science student to science teacher: Pre-service teachers' views and experiences learning to teach inquiry, Journal of Science Education, Vol.24, No.3, 427-447, 2017.

[32] C. Kearney. Efforts to Increase Students, Interest in Pursuing Science, technology, Engineering, and Mathematics Studies and Careers, National Measures taken by 21 of European School net's Member Countries-2011 Report. Brussels: European School net, 2011. 
[33] C. W. Keys, L.A. Brayan. Co-constructing inquiry-based science with teachers: Essential research for lasting reform, Journal of Research in Science Teaching, Vol. 38, No. 6, 631- 645, 2001

[34] M. Kim, A. Tan. Rethinking difficulties of teaching inquiry-based practical work: from elementary pre-service teachers, International Journal of Science Education, Vol.33, No.4, 465-486, 2011.

[35] C. M. Knaggs, T.A. Sondergeld. Science as a learner and as a teacher: Measuring Science self-efficacy of elementary pre-service teachers, School Science \& Mathematics, Vol. 115, No.3, 117-128, 2015.

[36] C. Redman. Science Teacher Education Partnerships with Schools (STEPS): Partnerships in science teacher education, Australian Journal of Teacher Education, Vol.39, No.12, 2014. http://dx.doi.org/10.14221/ajte.2014v39n12.4

[37] J. Ireland. Approaches to inquiry teaching: Elementary teacher's perspectives, International Journal of Science Education, Vol. 36, No. 10, 1733- 1750, 2014.

[38] J.M. Lakin, C.S. Wallace. Assessing dimensions of inquiry practice by middle school science teachers engaged in a professional development program, Journal of Science teacher Education, Vol.26, No.2, 139-162, 2015.

[39] A.W. Lazonder, R. Hamsen. A meta-analysis of inquiry-based learning: Effects of guidance, Review of Educational Research, Vol.86, No.3, 681-718, 2016.

[40] O. Lee, J.E. Hart, P. Cuevas, C. Enders. Professional development in inquiry-based science for elementary teachers of diverse student groups, Journal of Research in Science Teaching, Vol.41, No.10, 1021-1043, 2004.

[41] C. K., Lee, M. Shea. An analysis of pre-service elementary teachers' understandings of inquiry-based science teaching, International Journal of Science Education, Vol.27, No.2, 219-237, 2016.

[42] L.L. Liang, G.M. Richardson. Enhancing prospective teachers' science teaching efficacy beliefs through scaffolded, student-directed inquiry, Journal of Elementary Science Education, Vol. 21, No.1, 51-66, Winter 2009.

[43] L.L. Liang, D.L. Gabel. Effectiveness of a constructivist approach to science instruction for prospective elementary teachers, International Journal of Science Education, Vol.27, 1143-1162, 2005.

[44] C. R Lotter, S. Thompson, T.S. Dickenson, W. F. Smiley, G. Blue, M. Rea. The Impact of Practice-Teaching Professional Development Model on Teachers' Inquiry Instruction and Inquiry Efficacy Beliefs, International Journal of Science and Mathematics Education, Vol.16, No.2,255-273, 2018.

[45] J. L. Maeng, R.L. Bell, T. St. Clair, A. L. Gonczi, B. A. Whitworth. Supporting elementary teachers' enactment of nature of science instruction: a randomized controlled trial, International Journal of Science Education, Vol.40, No.18, 2245-2264, 2018. https://doi.org/10.1080/09500693.2018. 1528643

[46] P. Magee, R. Flessner. Collaborating to improve inquiry-based teaching in elementary science and mathematics methods course, Science Education
International, 23, Vol.4, 353-365, 2012.

[47] W. Melville, X. Fazio, A. Bartley, D. Jones. Experience and reflection: Pre-service science teachers' capacity for teaching inquiry, Journal of Science Teacher Education, Vol.19, 477-494, 2008. doi:10.1007/s10972-008-9104-9

[48] J.N. Mikeska, T. Shattuck, S. Holtzman, D.F. McCaffrey, N. Duchesneau, N. Qi. Understanding science teaching effectiveness: examining how science -specific generic instructional practices relate to student achievement in secondary science classrooms, International Journal of Science Education, Vol.39, No.18, 2594-2623, 2017.

[49] D.D. Minner, A.J. Levy, J. Century. Inquiry-based science instruction-What is it and does it matter? Results from a research synthesis years 1988 to 2002, Journal of Research in Science Teaching, Vol.47, No.4, 474-496, 2010.

[50] J. Mintzes, B. Marcum, C. Messerschmidt-Yates, A. Mark. Enhancing self-efficacy in elementary science teaching with professional learning communities, Journal Science Teacher Education, Vol. 24, No.7, 1202-1218, 2013.

[51] P.D. Morrell, J.B. Carroll. An Extended Examination of Pre-service Elementary Teachers' Science Teaching Self-Efficacy, School Science and Mathematics, Vol.103, No.5, 246- 251, 2003.

[52] J. Mulholland, J Wallace. Teacher induction and elementary science teaching: enhancing self-efficacy, Teaching and Teacher Education, Vol.17, 243-261, 2001 doi:10.1016/S0742-051X(00)00054-8

[53] J. Nam, J, E. Seung, M. Go. (2013). The effect of a collaborative mentoring program on beginnings science teachers' inquiry-based teaching practice, International Journal of Science Education, Vol.35, 815-836, 2013.

[54] R. Narayan, D. Lamp. "Me? Teach science?" Exploring EC-4 pre-service teachers' self- efficacy in an inquiry-based constructivist physics classroom, Educational Research, and Reviews, Vol.5, 748-757, 2010.http://www.academicj ournals.org/journal/ERR/article-full-text-pdf/317F0E7421 2

[55] National Research Council. Inquiry and the national science education standards: A guide for teaching and learning, National Academy Press, 2000.

[56] M. Papaevripidou, M. Irakleous, Z.C. Zacharia. Using teachers' inquiry-oriented curriculum materials as a means to examine their pedagogical design capacity and pedagogical content knowledge for inquiry-based learning, Journal of Science Education, Vol. 28, No.4, 271-2992, 2017.

[57] F. M Pajares. Self-efficacy beliefs in academic settings, Review of Educational Research, Vol.66, 543-578, 1996. doi:10.3102/00346543066004543

[58] D. H. Palmer. (2006). Durability of changes in self efficacy of pre-service primary teachers, International Journal of Science Education, Vol.28, 655-671, 2006. doi:10.1080/09500690500404599

[59] D. Palmer, J. Dixon, J. Archer. (2015).Changes in science teaching self -efficacy among primary teacher education students, Australian Journal of Teacher Education, Vol.40, No.12, 27-40, 2015. 
[60] M. Pedaste, M. Maeots, L. A. Siiman T. de Jong, S.A. Van Riesen, E.T. Kamp, E. Tsourlidaki. Phases of inquiry-based learning: Definitions and the inquiry cycle, Educational Research Review, Vol.14, 47-61, 2015.

[61] T. J. Posnanski. A redesigned Geoscience content course's impact on science teaching self-efficacy beliefs, Journal of Geoscience Education, Vol.55, No.2, 152-157, 2007.

[62] T. J. Posnanski. Professional development programs for primary science teachers: An analysis of teacher self-efficacy beliefs and a professional development model, Journal of cienceTeacherEducation, Vol.13, 189-220, 2002. http://dx.doi.org/10.1023/A:1016517100186

[63] A. Qablan. (2016).Teaching and learning about science practices: insights and challenges in professional development, Teacher Development, Vol. 20. No.1, 76-91, 2016.

[64] D. C. Rice, A. Roychoudhury. Preparing more confident pre-service primary science teachers: One primary science methods teacher's self-study, Journal of Science Teacher Education, VOl.14, 97-126, 2003. http://dx.doi.org/10.102 3/A:1023658028085

[65] G.M. Richardson, L.L.Liang. The use of inquiry in the development of pre-service teacher efficacy in mathematics and science, Journal of Elementary Science Education, Vol. 20, No.1, 1-16, 2008. doi:10.1007/2FBF03174699

[66] T.M. Scaria, P.B. Valsaraj, M. Pias. The Effectiveness of Video Teaching over Lecture cum Demonstration in Improving Knowledge and Skill of Nursing Students on Antenatal Examinations, International Journal of Nursing Education, Vol. 5, No.1, 228-230, 2013.

[67] J.H. Sandholtz, C. Ringstaff. Assessing the impact of teacher development on science instruction in the early elementary grades in rural US schools, Professional Development in Education, Vol.39, No. 5, 678- 697, 2013.

[68] I. Sandra, J.H. Walma, C. Poortman. Primary teachers conducting inquiry projects: effects of attitudes towards teaching science and conducting the inquiry, International Journal of Science Education, Vol.39, No.2, 238-256, 2017.

[69] G. Silm, K. Tiitsaar, M. Pedaste, Z.C. Zacharia, M. Papaevripidou. Teachers' readiness to use inquiry-based learning: An investigation of teachers 'sense of efficacy and attitudes toward inquiry-based learning, Science Education Journal, Vol. 28, No.4, 315- 325, 2017.

[70] R. Smit, H. Weitzel, R. Blank, F. Rietz, F. Tardent, N. Robin. Interplay of secondary pre-service teacher content knowledge (CK), Pedagogical Content Knowledge (PCK) and attitudes regarding scientific inquiry teaching within teacher training, Research in Science \& Technological Education, Vol.35, No.4, 477-499, 2017.

[71] M. Spittler. The Antecedents and Consequences of Teacher Professional Discretion over Curriculum and Instruction: A Grounded Theory Inquiry, A Doctoral Dissertation (Open Access), University of Central Florida, 2012.

[72] L.E. Swackhamer, K. Koellner, C. Basile, D. Kimbrough. Increasing the Self-Efficacy of In-service Teachers through Content Knowledge, Teacher Education Quarterly Spring, 63-76, 2009.
[73] B.G. Swan, K. J.Wolf, J. Cano. Changes in teacher self-efficacy from the student teaching experience through the third year of teaching, Journal of Agricultural Education, Vol.52, No.2, 128-139, 2011. doi;10.5032/jae.2011.02128

[74] M.M. Thompson, D. DiFrancesca, S.Carrier, C. Lee, Teaching efficacy: exploring relationships between mathematics and science self-efficacy beliefs, PCK and domain knowledge among pre-service teachers from the United States, Teacher development, Vol.21, 1-20, 2017.

[75] T. Tosun. The beliefs of pre-service elementary teachers towards science and science teaching, School Science \& Mathematics, Vol.100, 374-379, 2000.

[76] M.Tschannen-Moran, A. Woolfolk Hoy. Teacher efficacy: Capturing an elusive construct. Teaching and Teacher Education, Vol.17, 783-805, 2001

[77] W. Van Joolingen, Z.C. Zacharia. Developments in inquiry learning. In N. Balacheff, S. Ludvigsen, T. De Jong, A. Lazonder, S. Barnes, S., (Eds), Technology-Enhanced Learning: A Kaleidoscope View, Dordrecht: Springer-Verlag, 21-37, 2009.

[78] M. Voet, B. De Wever. Preparing pre-service history teachers for organizing inquiry-based learning: The effects of an introductory training program, Teacher and Teacher Education, Vol.63, 206-217, 2017.

[79] M. Voet, B. De Wever. Teachers' adoption of inquiry-based activities Education, the self, and the Context, Teacher Development, Vol.20, 1, 2017.

[80] C.S. Wallace, N.H. Kang. An Investigation of experienced secondary science teachers' beliefs about inquiry: An examination of competing for belief sets, Journal of Research in Science Teaching, Vol.41, No.9, 936-960, 2004.

[81] I. R. Weiss, J.D. Pasley, P.S. Smith, E.R. Banilower, D.J Heck. (2003). Inside the classroom: A study of K-12 mathematics and science education in the United States, Chapel Hill, NC: Horizon Research, 2003.

[82] M. Windschitl. (2004). Folk theories of "inquiry": How pre-service teachers reproduce the discourse and practices of an atheoretical scientific method, Journal of Research in Science Teaching, Vol.41,No.5, 481-512, 2004.

[83] W.A. Zimmerman, S. L., Knight, D.E. Favre, A. Ikhlef. Effect of professional development on teaching behaviors and efficacy in Qatari educational reforms, 2017.

[84] S.B.Gutierez. Collaborative professional learning through lesson study: Identifying the challenges of inquiry-based teaching, Issues in Educational Research, Vol.25, No.2, 118-134, 2015.

[85] A, S. Gencer, J. Carkiroglu. Differences between Elementary and Secondary Pre-service Science Teachers' Perceived Efficacy Belies and their Classroom Management Beliefs, Turkish Online Journal of Educational Technology. Vol.2, 2003.

[86] C.Tekkaya, J. Carkiroglu, O. Ozkan. Turkish pre-service science teachers' understanding of science and their confidence in teaching it, Journal of Education for Teaching: International Research and Pedagogy, Vol.30, No.1, 57-68.2004 doi: 10.1080/0260747032000162316 